\title{
The making of Portuguese Human Resources Management (1959-1986): regime change and the prevalence of normative discourse
}

\author{
José Nuno Matos
}

To cite this article: José Nuno Matos (2016) The making of Portuguese Human Resources Management (1959-1986): regime change and the prevalence of normative discourse, Management \& Organizational History, 11:3, 298-317, DOI: 10.1080/17449359.2016.1218775

To link to this article: http://dx.doi.org/10.1080/17449359.2016.1218775

曲 Published online: 05 Aug 2016.

Submit your article to this journal $\pi$

Џ Article views: 16

Q View related articles $₫$

View Crossmark data \lceil 


\title{
The making of Portuguese Human Resources Management (1959-1986): regime change and the prevalence of normative discourse
}

\author{
José Nuno Matos \\ Institute of Social Sciences, University of Lisbon, Lisbon, Portugal
}

\begin{abstract}
The development of Human Resources Management in Portugal reveals how national features may prevent or postpone the adoption of mainstream management models. Based on an analysis of the magazines Indústria Portuguesa, edited by the Portuguese Industrial Association, and Pessoal, by the Association of Portuguese Human Resources Technicians and Managers, this paper aims to understand how political events in the period between 1959 and 1986 came to shape a very distinctive configuration of management discourses. Contrary to what happened in more developed countries, the political effort to modernize productive structures, from the end of the 1950s, and the onset of the revolutionary process in 1974, in the wake of the fall of the authoritarian regime, determined the pervasiveness of normative concepts. Only in the mid-1980s, faced with a new political scenario and against the backdrop of a new shape of the labor movement, would Portuguese management lay emphasis on rational procedures.
\end{abstract}

\section{KEYWORDS}

Portugal; Estado Novo; management model; normative discourse; rational discourse

\section{Introduction}

In 1959, Portugal joined the European Free Trade Association (EFTA), which implied phasing out the country's custom barriers. Despite positive results in industrial exports since the early 1950s, this decision posed a serious challenge to the only non-industrialized country in EFTA (Lains and Coppollaro 2013). That same year, Estado Novo would launch its Second Development Plan (1959-1964), more specifically directed at industrial development and essentially backed by public funds. Aimed at reducing the country's dependency on imports, this new focus on industry would lead to the creation of a series of public institutions designed to promote new forms of company management. Headed by members of social catholic groups, these organizations, alongside business and professional associations, were the main factors behind in the introduction of a Human Relations approach in Portugal.

The purpose of this article is to understand the development of Human Resources Management (HRM) thought in Portugal from 1959 to 1986, the year Portugal joined the European Economic Community (EEC). Regarded as a milestone even prior to the 
establishment of the democratic regime, joining EEC raised hopes for political and economic consolidation. On the other hand, it sparked fears of a wider and tougher competition. It presented a challenge that pushed companies to undergo a series of structural changes, particularly in their management practices.

Although most of HRM knowledge was imported, its reception took place in the context of singular political, social and economic conditions. Even when compared to relatively similar countries, such as Spain (Guillén 1994; Rodríguez and Gantman 2011; Rodríguez-Ruiz 2014), one can point to a series of significant historical differences. One should bear these differences in mind and carefully weigh their relevance in shaping the distinctive traits of Portuguese HRM. There is a clear gap in social science research on this subject, which needs to be addressed. To this end, the present study will, firstly, consider the ground-breaking work of a series of public and private bodies. Among these, the Portuguese Industrial Association (AIP) and their magazine Indústria Portuguesa, which played a key role in disseminating management theory and practice in Portugal, publishing scientific papers and reports by economists and sociologists (mostly researchers from corporatist public bodies) and in promoting events organized by other institutions (the National Institute for Industrial Research, in particular) as well as by its Productivity Commission (COPRAI).

The end of the fascist regime, after a coup d'état by the Armed Forces Movement on 25 April 1974, raised expectations of a more conscious business class, who saw in this event an opportunity for productive and economic development. However, the first months of 1974 would prove trying, given the 'gap between workers' demands and the capacity of companies to meet them' (CIP 1974, 625), ${ }^{1}$ according to the newly created Confederation of the Portuguese Industry (CIP). By the end of the year, the magazine would cease publication.

Approximately one year later, in 1976, the Association of Portuguese Personnel Heads and Directors (APDCP) would print the first issue of Pessoal. Originally published as a news bulletin, its main contents are translations from HRM foreign magazines, articles by its associates and conference papers. Its publication would be subject to several interruptions, as well as a few upgrades, namely the change into a magazine later on, in 1983.

Through a content analysis of the articles published by Indústria Portuguesa (1953-1974) and Pessoal (1976-1986), I will seek to identify the key features of their discourse. These, however, should be uncoupled from the (more or less conflictual) relationship between managers and other organizations, trade unions and companies in particular. The paper begins by analyzing the reception and dissemination of HRM knowledge during the 1960s. As will be shown, this was in line with the new corporatism championed by Catholic groups within the regime, as both doctrines stood for a form of management grounded on technical competences and accountability to workers. Secondly, it will examine how the revolutionary process was understood by HR managers and APDCP associates. Despite fierce criticisms, their stance cannot be reduced to complaints about the unfairness of the process, as they also recognized potential opportunities in some of the revolutionary experiences of the time. As the paper draws to a close, I look at the shifts in management discourse brought about by the process of political stabilization and by the increasingly tangible prospect of joining the EEC, through an analysis of its legal framework and a comparison with management practices in other countries. Despite the persistence of structural problems, the establishment of institutionalized forms of conflict and dialog, alongside a series of labor reforms put in place at the time, allowed managers to keep up with HRM global trends towards more flexible labor relations. 


\section{The historical development of HRM discourse: concepts and method}

In light of these aims, this study is grounded on an historical analysis which, while focusing on the points of view and diagnoses published in the HRM press, brings into question the universalism and presentism that so often define the discourse produced in HRM (Booth and Rowlinson 2006). The concepts and classifications most widely spread among the managerial class, namely in magazines and conferences, contributed to the compilation of an initial archive. The question then became one of how, in the term of Michel Foucault, to find 'a way of limiting its domain, of defining what it is talking about, of giving it the status of an object - and therefore of making it manifest, nameable, and describable' (Foucault 2002, 46). The precise disposition of the final objects of study and action - the workers - and the employment of a strategy that would not rule against and/or over them, but rather through them, implies that those in charge are, first and foremost, in charge of managing their own selves (Foucault 1991, 91; Gay, Salaman, and Rees 1996).

To achieve this purpose, however, hinges on a number of conditions and organizational problems, which may have structural-economic roots, an international context or be related to specific political events (Guillén 1994, 21). The configuration of these problems, in turn, will determine the prevalence of a normative or a rational managerial discourse (Barley and Kunda 1992; Abrahamson 1997; Rodríguez-Ruiz 2014). The first hinges on a soft and collaborative approach, aimed at the promotion of shared values and beliefs among the workers as a means to fostering their moral commitment to the company. The latter, in contrast, is rooted in a hard and calculative point of view, emphasizing the relationship between the optimization of productivity and the enforcement of specific techniques, directed at maximizing workers` abilities and relying more on their self-interest than on winning their hearts and minds (Legge 1995; Gooderham, Nordhaug, and Ringdal 1999).

The hegemony of a specific kind of managerial discourse is subject to historical fluctuation. Barley and Kunda (1992) frame this development through an alternation model according to which a normative approach is always followed by a rational one, and vice versa. Based on this thesis, Abrahamson (1997) links these changes, on the one hand, to pendulum swings that occur in conjunction with Kondratieff's cycles of macroeconomic expansion (rational discourse) and contraction (normative discourse); and, on the other, to a performance-gap between 'the levels of performance that managers in these organizations aspire to, and the levels they actually do attain' (Abrahamson 1997, 492). According to these authors, and for the historical period spanned in this study, the evolution of managerial discourse follows these stages ${ }^{2}$ : Scientific Management (rational), Welfare Capitalism/Human Relations (normative), Systems Rationalism (rational), Organizational Culture (normative) and, in Abrahamson (1997), Flexible Rationalism (rational). Table 1 summarizes these models' key principles.

\section{The evolution of HRM during Estado Novo}

In the aftermath of the World War II, Portugal launched its First Development Plan (19531956), an obligation imposed by the signature of the Marshall Plan, earlier in 1947 (Lains 2003, 172). Its main goal was to guarantee the infrastructures (energy and transports, for example) necessary for industrial development. Although public funds only amounted to a small percentage of the total investment, this initiative implied a reversal of the country's economic policies, henceforth in line with international patterns (idem, 174). 


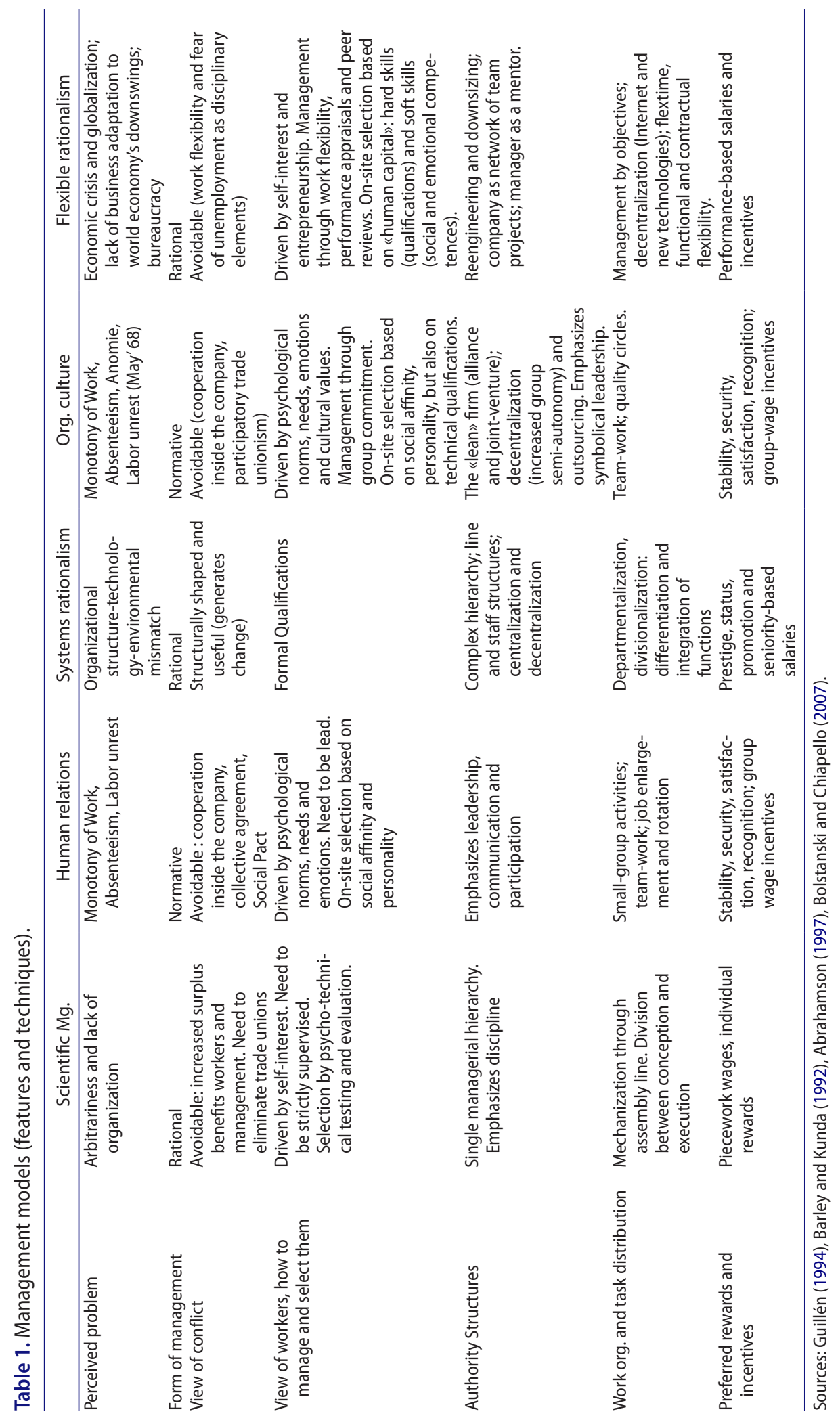


The focus on industry meant the country had to face up to its structural problems, namely the lack of qualified technicians and managers. In 1956, the government would establish a Corporative and Social Qualification Plan, which determined the creation of an Institute for Social and Corporative Qualification and a Corporative and Social Studies Board, founded later in 1959. The National Institute for Industrial Research (INII), created that same year, had similar objectives. Its main activities would be carried out by two departments: one was responsible for technological matters (related to fixed capital), while the other handled work relations (Indústria Portuguesa 1959, 55). In these capacities, both institutes would organize several courses and workshops on productivity and management. Later on, in 1962, the Ministry of Corporations would create the Institute of Social Studies, devoted to the creation of graduate courses (on Company Social Management, for example) originally directed at its technical staff (Ágoas 2010, 13).

These institutes represented a second push for corporatism, one that looked toward a deproletarianized industrial development. Contrary to what had been the rule thus far, these changes pointed in the direction of an autonomous corporatism. According to Pires Cardoso, director of the Corporatist Studies Board (1949), this doctrine is based upon 'free initiative in the constitution of corporative organisms, free inscription, and autonomy in the management of interests' (Cardoso 1950, 2). As was the case in Spain, these principles were championed by Social Catholicism, which saw in them an alternative to both Capitalism and Socialism. Indeed, some of the researchers at the Corporatist Studies Board (Adérito Sedas Nunes, Raul da Silva Pereira, Mário Murteira, Alfredo de Sousa, Maria Manuela Silva or Mário Cardoso dos Santos) were former members of the College Catholic Youth. Their works, published in the Review of the Corporatist Studies Board (1950), would cover a series of research areas, including the description and analysis of the Hawthorne studies by Elton Mayo, and favoured some of the latter's techniques, such as suggestion boxes or communication groups (Silva 1958). The idea of a corporatism-from-below, in which workers, managers and employers would spontaneously associate themselves, had found a common ground with the Human Relations approach.

This group of researchers was headed by Adérito Sedas Nunes, a prominent figure in the Portuguese Social Sciences. After a brief period as director of the Corporative and Social Studies Board, he would become the main driving force of the Social Research Board, in the School of Economic and Financial Sciences (1962). This center contributed to a greater institutional and scientific autonomy of social sciences research, particularly through its magazine Análise Social (Ágoas 2010, 35). Defined as'a tool for the most exact and thorough reflection on social issues' (Nunes 1988, 38), it would publish, from its very first issue, several articles on Human Relations and the principle of cooperation between workers and employers.

Alongside the state, some private interest groups also began to converge around these approaches. The Institute for the Scientific Work Management, part of the Institute of Languages and Management, and the Institute of Applied Psychology, financed by Catholic congregations, would be founded in 1962 (Bairrão 1968, 747). Two years later, the Institute of New Professions began its activity, offering graduation courses on Management Direction and Corporate Psycho-sociology. In 1963, managers from big companies, such as CUF (Raúl Caldeira), SACOR (Henrique Santa Clara Gomes), SONAP (Pedro Cabo Fernandez) or Lisnave (Manuel Bidarra), ${ }^{3}$ would join efforts in the APDCP. The collective took the place of the former Study Group on Personnel Management, working inside INII. ${ }^{4}$ According to a statement from its president Raúl Caldeira, its aim was to reverse the 'lack of relations among Personnel 
professionals' (apud APG and Venda 2004, 10), mostly through meetings and conferences. Some of its key figures, namely Henrique Santa Clara Gomes (head of the association in 1969) and Manuel Bidarra would later belong to SEDES - Association for the Economic and Social Development, a Christian Democrat political group. In the words of Castilho Soares, ${ }^{5}$ APDCP president in 1974,

while the association was - certainly - not a school of «common sense revolutionaries» (as Gramsci put it), it was, nonetheless, a valuable propaganda instrument for the most modern of management techniques, and the most evolved forms of human management in companies and work relations. (Soares 1976, 76)

Finally, one should also mention the work developed by the Work Industry and Managers Catholic Association (UCIDT). Created in the early 1950s, this organization would reach a greater visibility only a decade later, in 1962, with the edition of its magazine Empresa and the creation of a Social Studies Board, coordinated by Maria Manuela Silva (Social Research Board). According to the concluding remarks at its first national conference, UCIDT regarded companies as moral communities in which, under the banner of a God-given right to private property, all its members should take part. From their point of view, a company's personnel should 'be informed of the company's global activity; have an effective participation in the management of social care, as a means to foster responsibility; be consulted on technical issues related to well-being and better work productivity' (Associação Industrial do Norte [AIN], 1962, 11).

In 1963, AIP created a commission for productivity, in a joint effort with other organizations, such as INII, the Lisbon and Oporto Commercial Associations, the Professional Order of the Engineers and the Technical University. COPRAI would function as a non-profit consultancy agency, ${ }^{6}$ promoting conferences, courses, workshops, ${ }^{7}$ surveys and studies, as well as field trips to companies abroad (Italy or France). In its monthly column in Indústria Portuguesa, the organization would not only publicize their activities, but also publish research results and articles on management theory. Among their authors, some of whom were foreign, we find members of APDCP (Rául Caldeira) and INII, mostly engineers, ${ }^{8}$ a testimony of the close ties between public boards and private associations.

Most articles on management-related topics in Indústria Portuguesa (Table 2) point to a greater emphasis on Human Relations, particularly with regard to workers, their motivations and managers' attitudes towards them. As stated in one of its editorials, it was time to transcend 'the narrow technicality that has turned the machine into the condition and decisive instrument of economic progress' and thus to embrace'the wide movement for Man's rehabilitation as the leading factor in the economy' (AIP 1963, 189). Still, this insight was essentially theoretical, promoting general principles and providing basic guidelines for managers to apply. In spite of the efforts by these organizations, the conditions necessary for this venture were far from guaranteed. In fact, the need for governmental approval on any change in machinery and equipment imposed by the Law of Industrial Conditioning had postponed the introduction of Scientific Management techniques (Lima 1982; Gonçalves 1991). Thus, the welcoming of new trends of thought in HRM, both within Human Relations and Systems Rationalism, seems to have been restricted to a small techno-structure of state executives and managers from big companies (Santos 1977; Makler 1979). This lack of interest among the business class is attested by the evolution of the way these issues were reported in Indústria Portuguesa, as COPRAl's monthly column was reduced to the publicizing of its courses. 


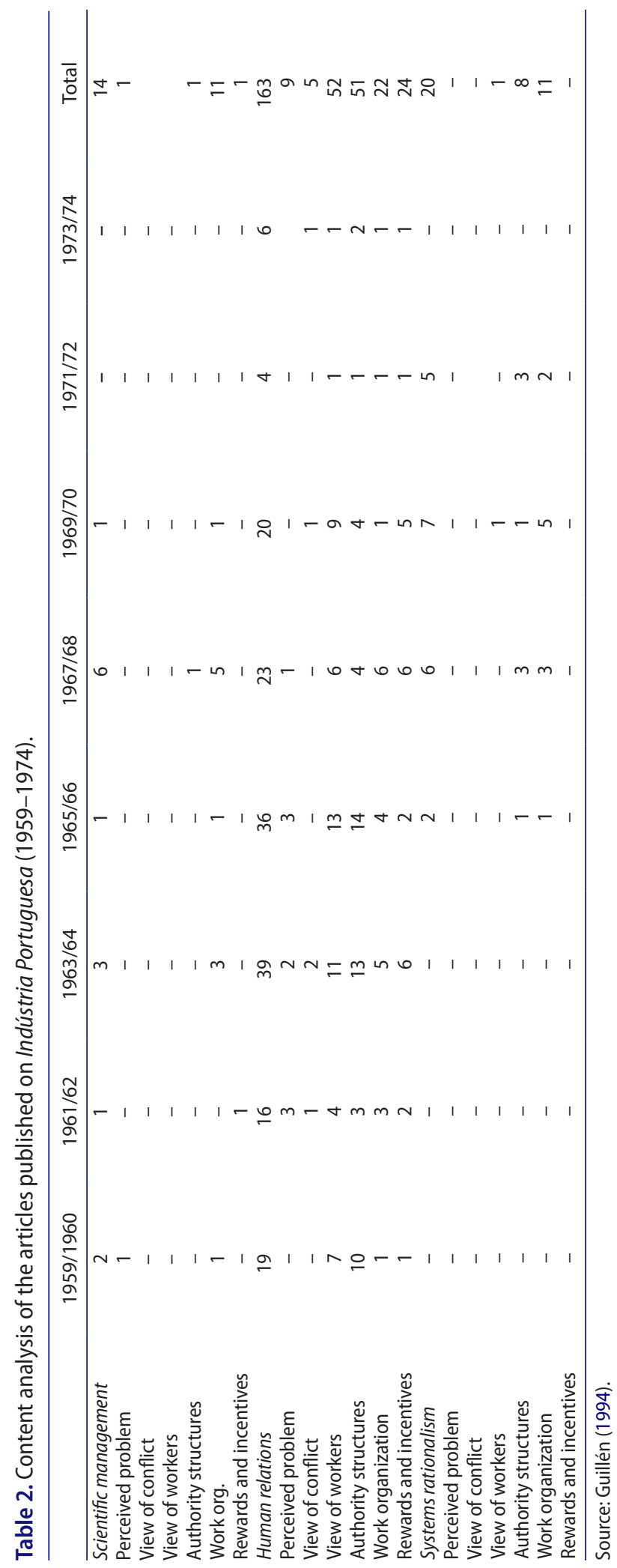


In 1968, Marcelo Caetano became prime minister, taking the place of a debilitated Salazar. The political changes which were then introduced sparked the hopes for a democratic transition and economic development. Initiated that same year, the Third Development Plan (1968-1973) would establish as one of its goals the development of participatory forms of management through corporative organization and improvement of human relations. One year later, the government would soften regulation on corporative trade unions and collective bargaining. The result, however, did not match the plan, as trade unions became strongholds for the democratic opposition. Soon later, the government would retreat and fall back on its former means of dealing with political organization and protest.

The war on African liberation movements not only stood in the way of public investment needed to reconfigure economic structures, but also led to an increase in the already high levels of emigration to Europe. As a result, the labor force diminished and, more importantly, became increasingly conscious of the political consequences of this demographic change. Be that as it may, reformist demands for higher rewards and incentives, as the ones produced in the Conference of Industrial Policy (1970) organized by AIP, were never seriously considered. The rise of inflation, as a result of the world economic crisis, was eventually the straw that broke the government's back, leading to strikes and other forms of labor unrest in 1973 and throughout the following years.

\section{HRM and the revolutionary process}

Although APDCP members did not suffer from any kind of political repression prior to 1974, their records bring to light a clash of ideas with the former regime, as confirmed by the political police's surveillance of their activities, on the grounds of international contacts with foreign associations, as part of the European Association for Personnel Management. However, the beginning of the May movement, in the wake of the 25 April revolution, would not spare managers, as reported by Henrique Santa Clara Gomes,

On April 25th, after the so-called democratic revolution, it was as if all the hate ..., that is to say, the ones at risk were the personnel directors, when in fact they were nothing more than delegates, trying their best in terms of human respect, concern, respect for the work, appreciation for the functions performed by each one, labour rationalization. But after April 25th, they had to find a scapegoat, no matter what. And the personnel directors got the short end of the stick. (apud APG and Venda 2004, 40)

In bigger companies, the May movement implied a fight against management on the part of workers' and trade union committees which would later include workers' control $^{9}$ and political cleansing. Reading through the first issues of Pessoal, as well as interviews with its founders (APG and Venda 2004), one can detect a feeling of resentment and injustice towards the revolutionary process which, in their view, had unfairly laid blame at their door.

After two failed military coups, led by far-right and conservative military officers (the first on 28 September 1974, and then on 11 March 1975), political measures against the business elite were taken, namely the nationalization of Portuguese banks by the newly created Council of the Revolution. ${ }^{10}$ For workers committees, this step not only confirmed their suspicions of economic sabotage, but also allowed the legal recognition of their power inside the company. As a very substantial part of the productive economy was concentrated, through stock exchange bonds, on a handful of financial and economic groups, a great number of technologically complex companies (services, chemicals, steel and metal) became 
public property (Makler 1979, 154; Noronha 2013, 291). This implied, according to historian Harry Makler, a push against managers, most of whom were employed in these companies (Makler 1979, 154).

The lay-offs, harassments and even arrests were, according to Álvaro Barreto, ${ }^{11}$ decided in general assemblies, whereas they should have resulted from'a carefully conducted process, with well-defined rules of engagement, and with guarantees of an impartial and unbiased judgment' (Barreto 1976, 59). These practices seemed, however, to have deeper (at least, less psychological) roots than that of the emotional state of their alleged perpetrators. Firstly, the class divide between workers and personnel managers, as the latter were, as a rule, recruited from the graduate ranks, and for the most part had middle-class- or upper class backgrounds (Alarcão e Silva 1976, 89). Secondly, if we follow the account of Manuel Alarcão e Silva, an APDCP member, most managers did search for'positions and privileges that were perhaps unfair, reinforcing a class mentality, refusing criticism and dialogue' (idem, 92). Finally, at the time, even those who were not suspected of fascist affiliations ${ }^{12}$ saw their authority questioned by a social movement that challenged the very notions of management and division of labor.

Subjected to forms of material and symbolic violence, managers tried to adapt to circumstances. On November 1974, APDCP organized its 7th Annual Conference, entitled «Reflections on Class Struggle and Personnel Management». Even though invitations addressed to Intersindical, ${ }^{13}$ as well as to USSR, Romania, Czechoslovakia and Hungary diplomats went unanswered, the association was able to count on the participation of Professor Stanislava Borkoswka, from Lodz University (in Poland) and of the Italian trade unionist Mario Umnia (APG and Venda 2004, 41). A few months later, Dragoljub Kavran, philosopher and member of the Jugoslav Public Administration Scientists Association, gave two talks in Portugal on the experience of industrial self-management in his country (Kavran 1976, 21). One year later, in 1975, the 8th Annual Conference would focus on the topic of «Work Relations in a Society in Transition to Socialism». In its closing remarks, APDCP stresses 'the refusal of the idea that workers' power must be exercised against managers, who are indeed workers themselves', and highlights the multiple'possibilities of a neutral use of techniques, devoid of class bias' (APDCP 1976, 22). In short, management was to be conceived as a domain of action that stood above and beyond the economic or political regime: whether capitalist or socialist, society needs managers.

The end of the revolutionary process, on 25 November $^{14}$ would gradually lead to the re-establishment of managers' powers. In 1976, closing the 9th Annual Conference of the renamed Association of Portuguese Human Resources Managers and Technicians (APGTRH), its president and HR specialist René Cordeiro reflected on the importance of conflict. Contrary to traditional analysis, which saw conflict merely as a problem whose resolution depended on the use of repressive means, the manager defined it as'a necessary ingredient in all forms of social organization' (Cordeiro 1976, 155). Throughout the conference, this line of reasoning would ascribe a new interpretation and meaning to workers' control. Its origin in companies, as opposed to larger economic areas of activity, was an expression, according to jurist Bernardo Xavier, of 'the extraordinary richness of workers' intervention in companies' (Xavier 1976, 19), namely through political cleansing:

The fact is that even the businessman [...] has started to rely on the acceptance, if not the trust, of the workers' community. I will not discuss whether that was good or bad, or if the path followed was right or wrong [...]. We only need to look at the Government's Bulletin to confirm 
that in the various public interventions in private companies the nomination of Mr. X or Mr. Y, so one reads, is based on the trust placed on them by workers, because they were elected by workers' committees, etc. etc. The examples are numerous and they could be multiplied. What happens to the superior strata of the company happens, a fortiori, to the company's managers. The whole of the massive movement designated as political cleansing corresponded to that reality, the direct influence of the work community on company managers. I repeat - I am not putting forward a critical view on this issue, I am merely pointing out the facts. (idem, 20)

The answer, so it seemed, was to fall back on normative forms of control which, influenced by the Human Relations approach, considered work groups as the ultimate point of integration and imposed on managers the soft skills designed to meet this requirement, such as communication, motivational or inspirational and group management skills (Barley and Kunda 1992, 375). What is more, the prevalence of a normative discourse is related to labor unrest (strikes, for example), and the creation of work groups and the improvement of workers' conditions functioned as pre-emptive means and alternatives to union organization and activity (Guillén 1994, 25; Abrahamson 1997, 524), with managers in the role of trouble-shooters (Rodríguez-Ruiz 2014, 265).

\section{The Social Pact and the search for a «prevailing situation»}

A new relationship between workers and management, based on involvement rather than conflict, would, first of all, imply winning trade union support. The legislative regulation of relations of production ${ }^{15}$ had established the trade union as the social partner par excellence, compelling companies, represented by managers, to negotiate with it. Although this founding principle was, at least in theory, consensual, putting it in practice was by no means an easy task.

Collective bargaining demanded, according to some of APGTRH's most prominent figures $^{16}$ a less peremptory trade-unionism and a less interventionist state. The authors stress 'a particularly extensive set of governmental policy apparatuses that cut across the terrain of collective bargaining' (Cordeiro et al. 1980, 101, 39), such as minimum salary indexes or labor regulatory ordinances, which implied 'the restriction of the manager's right to make decisions' (idem, 38). The concern was, therefore, with the lack of power over domains which, as they saw it, should be their sole responsibility (recruitment, career progression, scheduling, among others).

Such strategy was most present in public companies - since the private sector was mainly composed of small and medium-sized companies with a low level of trade union membership - where trade unions' main focus lay on bargaining over economic matters (wages, for example) (Fernandes et al. 1980, 91). The aim, however, was not to eradicate collective bargaining but, instead, to steer it towards the creation of a balanced framework of social relations (Barley and Kunda 1992; 374). Putting these thoughts into practice required, according to Monteiro Fernandes, the signing of a Social Pact between government, companies and trade unions. More than being defined by a specific set of policies, the Social Pact was a procedure that was not based on 'the outlook of an ideology or idea - it is pragmatically imposed by the complex and indivisible nature of the prevailing situation' (Fernandes 1983, 8).

The focus on the prevailing situation is, from our own point of view, related to a string of developments which brought about a scenario of more stable and increasingly balanced work relations. Firstly, the creation of the General Union of Workers (UGT), ${ }^{17}$ in 1978, implied the emergence a new kind of trade unionism, one which, unlike Intersindical, would regard 
negotiation and participation as key ideological principles. Secondly, some of the most powerful workers' committees, such as the one at the shipbuilding company Setenave, would eventually sign agreements with the Management Board. ${ }^{18}$ This took place after two structural adjustment programs had been signed with the International Monetary Fund in 1979 and 1983. The economic crisis, the rise of unemployment or the non-payment of salaries would diminish workers` strength and willpower, which translated into a decrease in strikes and trade union membership in the following years (ILO 2016; Cerdeira and Padilha 1990, 25). ${ }^{19}$ A more institutional form of participation was therefore a means for trade unions to mitigate the effects of these changes, in which we can include the increasing concentration of employment in services. One year later, the Permanent Commission for Social Consultation $(\mathrm{CPCS})^{20}$ would be created, bringing together trade unions and business associations (CGTP-IN would only join in 1987). More symbolically than materially, this congregation of conflicting interests was presented as an example to be followed by every other company in Portugal.

\section{From human relations to organizational culture}

The revolutionary process had undoubtedly pushed back the development of HRM in Portugal. In any case, the set of problems managers were faced with was far from having been triggered solely by workers' antagonism, as shown by a survey conducted by the association in 1976, to which 50 professionals responded. ${ }^{21}$ With regard to a familiarity with motivational theories, for example, most respondents had an up-to-date knowledge of authors such as Maslow («hierarchy of needs»), Herzberg («two-factor theory») and McGregor («theory $x$ and theory $y »$ ) (Cordeiro 1976). Nevertheless, trying to put this knowledge into practice, an effort made by $59 \%$ of the respondents, produced modest results in $60 \%$ of the companies they worked in, the symptom of a 'particular individual and business - in other words, organizational - environment that usually does not exist' (Cordeiro 1976, 20). This lack of interest in the development of HRM is also attested by the absence of a participatory form of management in $60 \%$ of their companies. Among the companies that did include it, there was not a single one that employed more than 2000 workers (idem, 34). Finally, despite the general relevance given to on-the-job training, most companies, even the largest ones, seemed to be quite indifferent to this matter, compelling managers to resort, by their own means, to external services (see Table 3).

These results seem to point to a degree of indifference towards HRM, even in the context of a democratic opening. Though one can point to the institution of some public research boards under the umbrella of the Ministry of Labor, as the Department of Research and Planning or the Work Sociology Division, progress in this area was slow. Some curricular modules were introduced into public universities, but in most cases they were merely optional (Lima and Rodrigues 1987). In 1977, the Portuguese Association of Managers is created, and included leading figures from APGTRH, namely Raúl Caldeira. However, Pessoal would remain the only HR magazine to be published in Portugal in this period. ${ }^{22}$

The preponderance of articles ${ }^{23}$ defending the Human Relations model (1976-1981) can therefore be interpreted not only as a feature of the post-revolutionary context, but also as a sign of the search for a recognition of their own professional competences by company owners and society as a whole (Table 2). At the same time, some relevance is given to the Systems Rationalism form, namely through the publication of works from foreign magazines 
Table 3. Content analysis of the articles published on Pessoal (1976-1986).

\begin{tabular}{|c|c|c|c|c|c|c|c|}
\hline & $1976 / 77$ & $1978 / 79$ & $1980 / 81$ & $1982 / 1983$ & $1984 / 85$ & 1986 & Total \\
\hline Human relations & 61 & 40 & 28 & 9 & 6 & 1 & 145 \\
\hline Perceived problem & 16 & 7 & 11 & 5 & 2 & 1 & 42 \\
\hline View of conflict & 9 & 9 & 4 & - & 1 & - & 23 \\
\hline View of worker & 10 & 5 & 5 & - & - & - & 20 \\
\hline Authority structures & 17 & 18 & 7 & 4 & 3 & - & 49 \\
\hline Work organization & 8 & - & 1 & - & - & - & 9 \\
\hline Rewards and incentives & 1 & 1 & - & - & - & - & 2 \\
\hline Systems rationalism & 18 & 29 & 18 & 22 & 16 & 1 & 104 \\
\hline Perceived Problem & 2 & 3 & 3 & 4 & 1 & - & 13 \\
\hline View of conflict & 2 & 1 & - & 1 & - & - & 4 \\
\hline View of worker & 4 & 9 & 4 & 5 & 4 & - & 26 \\
\hline Authority structures & 5 & 7 & 3 & 4 & 3 & 1 & 23 \\
\hline Work organization & 3 & 5 & 4 & 5 & 7 & - & 24 \\
\hline Rewards and incentives & 2 & 4 & 4 & 3 & 1 & - & 14 \\
\hline Org. culture & - & 9 & 10 & 30 & 16 & 17 & 82 \\
\hline Perceived problem & - & 1 & - & 2 & - & 2 & 5 \\
\hline View of conflict & - & - & - & - & - & - & - \\
\hline View of worker & - & 1 & 4 & 12 & 3 & 5 & 25 \\
\hline Authority structures & - & 3 & 2 & 7 & 5 & 3 & 20 \\
\hline Work organization & - & 3 & 4 & 8 & 8 & 5 & 28 \\
\hline Rewards and incentives & - & 1 & - & 1 & - & 2 & 4 \\
\hline Flex. rationalism & - & - & 9 & 8 & 31 & 27 & 75 \\
\hline Perceived problem & - & - & - & - & - & 5 & 5 \\
\hline View of conflict & - & - & - & - & 1 & - & 1 \\
\hline View of worker & - & - & 5 & 4 & 16 & 11 & 36 \\
\hline Authority structures & - & - & 1 & 1 & 3 & 6 & 11 \\
\hline Work organization & - & - & 3 & 2 & 8 & 5 & 18 \\
\hline Rewards and incentives & - & - & - & 1 & 3 & - & 4 \\
\hline
\end{tabular}

Source: Guillén (1994).

(Brazil, Spain, France) or through articles defending a greater investment in work qualification or new technologies, particularly micro informatics. A conference paper on the subject, by an APGTRH representative, began precisely by comparing foreign and national investment policies. In Portugal, according to the association, the reduction of labor costs guaranteed by low wages in industry bred a lesser concern for the development of cutting-edge technologies (APGTRH 1982b, 4). And yet, the increase in computer sales between 1975 and 1980, as well as the introduction of IT graduate courses, were seen as encouraging news:

Just as industrial automation brought about the disappearance of the undifferentiated worker [...], office automation will make the undifferentiated bureaucrat disappear, as executive tasks will tend to be performed by those who have control over the parameters. It is important to cherish and support this trend. Otherwise, there is the risk of creating a new class of terminal operators and bureaucratic machines. (idem, 10)

However, as we can see in Table 2, the Systems Rationalism thesis never reached a dominant position within the magazine. Unlike what happened in countries like the United States (Barley and Kunda 1992), there is no swing between normative and rational managerial discourses, but rather the predominance of the first until 1984. The Human Relations model would thus give rise to a focus on Organizational Culture, particularly on the experiments carried out in postwar Japan, under the leadership of Taiichi Ohno, Toyota's executive vice-president. With the supermarket's provision structures in mind, the auto giant would apply a lean production system to a more flexible range of products, whose success demanded a greater concern with the client's opinion, as well as a just-in-time response to new consumer patterns (Coriat 1991, 29). Although the assembly line continued to be in 
place, workers were given a new set of responsibilities, such as maintenance and quality control. Changes in the work process were now subject to discussion, namely through Quality Circles (QC), groups that were composed of both workers and middle managers.

Pessoal paid great attention to this technique, namely through the edition of a special issue, where its qualities were described in great detail. The QC would have the ability to merge creativity and self-empowerment, based not on 'the adoption of Japanese cultural traits', but rather on what Tavares da Silva, former HR manager at Tabaqueira ${ }^{24}$ and APDCP founder, defines as the 'systematic use, across all levels, of industrial sociologists' and psychologists' theories on the rank and file' (idem, 10). Much like a community, the QC would operate as the basic infrastructure of 'personnel indoctrination' (Silva 1982, 6).

Articles on Toyotism and the QC often included critical remarks on national practices. In Portugal, according to Paulo Penim, Firestone's quality manager, the method had only been put into practice by Magnetics - Peripherals System, since 1982, and Firestone, where the first QC were starting at the time. The indifference towards this model was, in his opinion, due 'to the specific features of the Portuguese industrial population, determined by concentrated management, the changes brought about by 25 April, the financial and productivity crises of Portuguese companies' (Penim 1984, 39). This last element, alongside the already mentioned labor antagonism, explains the continuous prevalence of a normative discourse, since its devices could be seen as less costly than those of rational control (Abrahamson 1997, 502). The latter would imply an investment that Portuguese companies seemed less than keen on.

\section{Flexibility, the new management and life model}

The criticism directed at the type of management practiced by Portuguese companies is inseparable, as our analysis has shown, from the championing of a new type of company and, consequently, of new work relations. Since 1976, labor legislation had been subjected to some changes, namely the introduction of fixed term contracts. Although strict limits to unjustified dismissals were singled out as the main cause of the widespread application of this legal disposition, a few articles denounced the attempt 'to keep within an uncertain contractual regime many of the workers who could and should hold a job position on a permanent basis' (Fonseca 1979, 22). Even APGTRH, in the HRM Eurolatin conference, would classify this tendency as 'an «informal» and «non-institutional» employment market»' (APGTRH 1982a, 8). This, in turn, was directly related to the fact that the economy was based on low levels of labor and capital productivity (Lains and Coppollaro 2013, 77).

Two years later, the former APG head director Jorge Marques would employ a different set of terms, such as 'particular forms of employment' or'alternative solutions to unemployment' (Marques 1984, 8, 9). The promotion of these measures reflects the magazine's approach to Flexible Rationalism (Table 2). At first glance, this may be interpreted as a sign of a predisposition to consider HR models based on its (low) costs, attested by the scarce number of articles on rewards and incentives. However, a certain amount of focus on Systems Rationalism and Organizational Culture leads us to conclude that the new model cannot be reduced to numerical flexibility, as it included other dimensions, as part-time work and work reduction (idem, 8, 9). These policies, as Marques would later emphasize, were being implemented in many European countries, where the focus on work satisfaction and motivation was accompanied by a break with 'unrestrained collectivization' (Marques 1985, 31). 
The interventions at the annual conference «HRM: the Challenge of Crisis and the Modernization of the Economy», organized by APGTRH in 1985, would confirm the need to ensure that these European dynamics translated into the national sphere. The Education minister José Augusto Seabra underlined how the entry into the EEC, now deemed irreversible, ${ }^{25}$ would bring about changes in production and work relations that would imply not only investments but'an HR qualification, a professional qualification' (Seabra 1985, 37). The former TAP ${ }^{26}$ CEO João Botequilha would reinforce this view, claiming that for'human energies wasted in the sterile turmoil of political and ideological strife', there was 'no recourse other than [...] economic flexibility' (Botequilha 1985, 22). Besides cuts in public spending, the end of state monopolies, this should also include the 'flexibility of the status that determines the worker's relation to the company' (idem, 22). A more thorough analysis of this program would be presented by Fernando Adão da Fonseca, at the time director of the Applied Research Centre of the Portuguese Catholic University and teaching fellow at the New University of Lisbon's Faculty of Economics. ${ }^{27}$ Beginning with a reflection on unemployment, the economist and consultant would consider that, besides the need to acknowledge the long-term effects of technological changes, its increase was tied to the 'relative cost of labour and energy' (Fonseca 1985, 14). Solving this problem would imply, as he saw it, profound labor reforms, with a view to

simplifying the regulatory legal frameworks that govern the provision of work. [...] In particular, it will be crucial to find ways to reinforce contractual freedom between the parties, as well to allow for the reduction of surplus HR and enable lay-offs based on objective criteria, a goal which is directly tied to the company's need for technological development, as well as to workers' non adaptability. (Fonseca 1985, 15)

For changes in the labor market to be effective they would have to go beyond the company and its work relations. Based on the balance between offer and demand, as in any market, the author proposed cuts in unemployment benefits, due to the

relation between unemployment benefit and the time period during which the unemployed will remain inactive before accepting a part-time job or one perceived as underpaid. The right to work is fundamental. However, to speak of the right to work with the salary one wishes for is nonsense. (idem, 14)

Placing a greater burden on the shoulders of the unemployed would allow for reductions on labor costs (idem, 15).

One year later, the concluding remarks of the 1986 annual conference «To develop men, to modernize organizations, to improve society» would define flexibility and creativity as the 'key conditions of the European industrial world', the first as the 'system's ability to react to various disturbances' and the second as the means to assure 'the development of a composed state of mind, one able to break with established routines at each turn' (APGTRH 1986).

\section{Concluding remarks}

The evolution of HRM in Portugal seems to have run along similar lines to the Spanish process. In the period between 1950 and 1974, both countries apparently share a number of key political and economic features, such as an authoritarian political regime, the increase in foreign investment, the migration of a large part of the surplus labor force (a positive contribution to the balance of payments) or a flourishing tourist industry (Guillén 1994, 183). Similarly, the two countries faced structural constraints, essentially due to the predominance of small-scale and nationally oriented businesses and, subsequently, to a lack of interest in 
the employment of human relations techniques and departments, with the exception of a few companies, often foreign-owned (idem, 198). What became known as the second push for corporatism was an attempt to reverse this situation, through the creation of public boards and state support for private associations. Their joint efforts would bring about the production and implementation of the knowledge required to guarantee social peace and greater levels of productivity, as well as for the organization of public events where managers were heralded as key agents of change (Gonçalves 1991). The governmental effort to promote a series of political and economic reforms came about after 1968, when Salazar was replaced by Marcelo Caetano. The changes in trade union regulation became a symbol of a new political approach, in which the influence of the Human Relations model was paramount. However, the effects produced by the world economic crisis, inflation in particular and the large portion of the budget spent on the war effort stood in the way of the promised improvement in working conditions. By the end of the 1960s, the regime was faced with growing political unrest.

Although Portugal and Spain can be folded within a Latin cluster, with a set of shared features (Brewster 1995; Gooderham, Nordhaug, and Ringdal 1999), there are historical variances which determine slightly distinct HRM developments. The revolutionary process in Portugal, in contrast to the Spanish Transición, is singled out as one of the main causes of the country's structural economic problems, fostering a mythologized past (Booth and Rowlinson 2006 11) that celebrates managers' perseverance, their resistance to all kinds of injustices or their ability to identify, when no one else did, the main problems and their solutions. The Spanish dictatorship had been faced with a resurgence of industrial conflict in the mid-1950s (and later on, in 1969), countered by a mixed strategy of repression and co-optation and, later on, by a series of political reforms designed to allow the regime to maintain control over a shifting political situation (Logan 1985, 165). While Uníon General de Trabajadores and Comisiones Obreras, the two largest Spanish trade unions, would sign the Pactos de la Moncloa, a 'critical institutional mechanism for stabilizing the economy' (Rodríguez-Ruiz 2014, 264) in 1977, in Portugal the Social Pact would only be signed in 1984.

While in Spain there was a tug between rational and normative solutions from 1973 to 1980 (Rodríguez-Ruiz 2014; 264), in Portugal the managerial discourse was predominantly normative. Besides the former regime's anti-industrialism, which created a stagnant and less entrepreneurial business class, as subsequently became clear, there was an emphasis on a normative discourse and, accordingly, lesser significance afforded to rational procedures, on the grounds of a need to address labor unrest. The semi-autonomous work group, supported by Human Relations and Organizational Culture models, was seen as a means of disarticulating rank and file labor organizations and sponsoring communities in and for the company, rather than against it. However, the revolutionary process was unable to move against traditional sector industries, mostly in textile and construction work (Makler 1979, 160), where, as a whole, the separation between ownership and management did not even exist (Cardoso et al.1990).

Although it represents a change in the managerial discourses and practices, from normative to rational, the turn to Flexible Rationalism does not necessarily entail a break with former concepts. Soft management practices are not only compatible with harder approaches or techniques, such as surveillance (Legge 1995, 45), they share the goal of keeping labor unrest under control. However, given that soft practices such as the QC were rare, it is the slow decomposition of the workers' movement that would allow for the required conditions for 
rational procedures to be put in place. Therefore, as claimed by the performance-gap thesis, one may conclude that the prevalence of a normative discourse is related to the level of labor union activity across organizations and, consequently, that the subsequent predominance of a rational discourse can be explained by its increasing absence (Abrahamson 1997, 504).

\section{Notes}

1. During 1974 and 1975, thousands of industries, estates and houses were occupied. Many companies continued their activity under workers' control. These events, part of the May movement, were supported by the media and state apparatuses, which at times took on an active role, in particular through the more radical left factions of the Armed Forces Movement. For a better understanding of the May movement, see Pinto (2013).

2. On the North American managerial discourse, Kunda and Barley present two earlier periods: Industrial betterment (1870-1900) and Scientific management (1900-1923) (Barley and Kunda 1992, 364).

3. CUF was a huge economic group that covered areas from banking and insurance to shipyard building (including Lisnave). SACOR and SONAP were, respectively, oil distribution and refinement companies. In 1975, all these companies were nationalized.

4. Lacking a head office, the association usually met at the companies where its members worked, or at the INII, which they classified as being 'perhaps slightly against the prevailing state of affairs' (apud APG and Venda 2004, 19).

5. Former Secretary for Health and Education in Angola during the first years of war (1961-1962).

6. CUF would also create its own consulting company (Lima 1982; 1328). Besides the companies that belonged to the group, NORMA worked with other clients (banks, insurance and public services), particularly in the fields of management, marketing, public relations and data processing (CUF 1974, 25).

7. As an example, in 1965 it would organize around 20 courses, with a total of 290 participants, mainly AIP associates (Marques 1965, 85).

8. Since its creation, AIP's management boards were mostly composed of engineers who had become businessmen (Makler 1979). Paradoxically, their employment would only increase in the 1950s, after the First Development Plan. As part of their job, they would be responsible for an array of management competences, as other kinds of professional expertise were either unknown or were just then starting to be taught at universities (Rodrigues 1999).

9. Workers ' Control can be defined as set of practices that take place during revolutionary crises, when state power is confronted by an acting and dynamic counter-power, with its own logic, organized from below by an array of rank and file organizations (dual power).

10. Composed by the President of the Republic and by the prime minister, as well as by high- and middle-ranking military officers, the Council of the Revolution congregated legislative and executive powers.

11. After his experience as CEO at Lisnave (1969-1971 and 1974-1978) and Setenave (1974-1978), Álvaro Barreto would be nominated Minister of Industry and Energy in 1978.

12. Some companies used to resort to the political police, hiring its services for the surveillance of workers or requesting information during recruitment and selection processes. Among these, we should mention CUF, Lisnave, SACOR, Firestone or Siemmens (Rosas et al. 2010, 213).

13. Intersindical, the Portuguese trade union confederation had, at the time, the monopoly of worker's representation. Later, in 1977, it would change its name to General Confederation of Portuguese Workers - Intersindical (CGTP-IN). It has been, until the present day, strongly influenced by the Portuguese Communist Party.

14. On that date, a military coup would remove all far-left officers from the MFA.

15. Law decree 164-A/76, of 28 February. 
16. Among them, the former president René Cordeiro and António Monteiro Fernandes, member of the board of directors and, later on, State Secretary for Employment (1995-1997).

17. UGT was created in the wake of the Open Letter Movement [Movimento Carta Aberta], headed by trade unions close to the Socialist Partly and the Social Democratic Party (mostly white-collar workers from banks, insurances and offices) which, in an open letter, defended the end of the monopoly of workers' representation by CGTP-Intersindical.

18. In a brief notice, Pessoal would praise this decision: 'In the Portuguese labour society, the new word for 1983 is social pact, social agreement, social consensus or social dialogue [...]. A social pact was signed between Setenave's workers and its Management Board. In the construction of the oil tanker «S-106», the six thousand workers agreed not to strike; not to go on holidays; and to freeze $6 \%$ of their salaries, whose payment will depend on meeting deadlines. Even overtime, shift premiums and other rewards will only be paid after the main stages of the construction plan are accomplished. An experience to follow until the end of 1983' (APGTRH 1983, 21).

19. Trade union membership evolved from $58.8 \%$ (1979-1984) to $51 \%(1985 / 1986)$. The number of strikes went from 602 (1981) to 363 (1986) (Cerdeira and Padilha 1990, 25; ILO 2016).

20. CPCS would be integrated, with full autonomy, in the Economic and Social Council (1989), a structure which, besides trade union confederations and business associations, includes other civil society associations: family, regional or municipal, among others. We should mention that CPCS's resolutions are merely pledges that can only become concrete measures and laws through formal decisions by the government and parliament.

21. The group of respondents, based on a non-representative study sample, was composed of high-level professionals (68\%), between 40 and 49 years of age; as well as medium (28\%) and low level (4\%) managers, both between 30 and 39 years of age. About $30 \%$ were working in companies with more than 301 and less than 500 workers; 14\% in companies with more than 2000 and less than 10,000 workers; and 12\% in companies with more than 500 and less than 1000 workers. Regarding their skills, $54 \%$ had a degree and $16 \%$ a bachelor's degree. There were some respondents who had dropped out of university and started working as managers without concluding their graduations (Cordeiro 1976, 12).

22. The Portuguese Management Association would start to publish Executive in 1986. One year later, the Institute of Employment and Professional Training would create Dirigir [to Lead], directed towards managers.

23. The content analysis of the articles was produced directly by the author, through the reading and interpretation of the articles, and their subsequent categorization within each management model. Articles that were not classifiable were not considered (Guillén 1994, 305).

24. The largest Portuguese tobacco company, nationalized in 1975.

25. The signing of the Constat d'Accord between Portugal and the EEC in 1984 marked the «irreversible nature» of the country's integration in EEC. It also defined 1 January 1986, as the date of accession (Cunha 2012, 163).

26. Portuguese Airline Company, publically owned at the time.

27. Both college institutions would contribute to a neoliberal critique of Keynesian economic policies.

\section{Disclosure statement}

No potential conflict of interest was reported by the author.

\section{Funding}

This work was supported by Fundação para a Ciência e Tecnologia [SFRH/BPD/96064/2013]. 


\section{Notes on contributor}

A graduate and master in Political Science, José Nuno Matos is a post-doctoral Research Fellow in Sociology at the Instituto de Ciências Sociais da Universidade de Lisboa. He has dedicated his studies to issues of work, management, and social movements. His current research activities focus on the relationship between journalistic practice and job precarity.

\section{References}

Abrahamson, E. 1997."The Emergence and Prevalence of Employee Management Rhetorics: The Effects of Long Waves, Labor Unions, and Turnover, 1875 to 1992." Academy of Management Journal 40 (3): 491-533.

Ágoas, Frederico. 2010. "Saber e Poder: Estado e Investigação Social Agrária nos Primórdios da Sociologia em Portugal." PhD diss., University of Lisbon.

AIP. 1963. "Os valores humanos na expansão industrial." Indústria Portuguesa 424 (36): 189.

Alarcão e Silva, Manuel. 1976. “Perspetiva da APGTRH.” Pessoal 19 (2): 85-98.

APDCP. 1976. "Alocução do presidente da Assembleia Geral da APGTRH." Pessoal 19 (2): 3-5.

APG, and Venda António Manuel. 2004. 40 Anos da Gestão das Pessoas em Portugal. Miraflores: Preâmbulo.

APGTRH. 1982a. "As influências na gestão do pessoal dos mais recentes desenvolvimentos políticos, económicos e sociais em Portugal." Pessoal 72 (7): 3-13.

APGTRH. 1982b. "A micro informática e a empresa de amanhã." Pessoal 78 (7): 3-14.

APGTRH. 1983. "Pacto Social» na Setenave." Pessoal 1 (8): 21.

APGTRH. 1986. "Conclusões." Pessoal 2324 (11): 87-87.

Associação Industrial do Norte [AIN]. 1962. "Simpósio Nacional da UCIDT." A Indústria do Norte 516 (13): 2-11.

Bairrão, Bernardo. 1968. "O Ensino da Psicologia em Portugal: situação e perspetivas". Análise Social, 4 (22-24): 730-762.

Barley, S. R., and G. Kunda. 1992. "Design and Devotion: Surges of Rational and Normative Ideologies of Control in Managerial Discourse." Administrative Science Quarterly 37: 363-399.

Barreto, Álvaro. 1976. "Conferência por um gestor." Pessoal 19 (2): 57-64.

Bolstanski, Luc, and Eve Chiapello. 2007. The New Spirit of Capitalism. London: Verso.

Booth, Charles, and Michael Rowlinson. 2006. "Management and Organizational History: Prospects." Management \& Organizational History 1 (1): 5-30. doi:10.1177/1744935906060627

Botequilha, João. 1985. "Quanto ao futuro nacional tudo vai depender das pessoas." Pessoal 13 (10): 21-23.

Brewster, Chris. 1995. "HRM: The European Dimension." In Human Resoource Management: A Critical Text, edited by John Storey, 309-331. London: Routledge.

Cardoso, José Pires. 1950. “Editorial." Revista do Gabinete de Estudos Corporativos 2 (1): 1-4.

Cardoso, José Luís, José Maria Brandão de Brito, Fernando Mendes, Maria de Lourdes Rodrigues. 1990. Empresários e gestores da indústria em Portugal. Lisboa: Dom Quixote.

Cerdeira, Maria, and Edite Padilha. 1990. A sindicalização portuguesa e alguns comportamentos sindicais. Lisboa: Ministério do Emprego e da Segurança Social.

CIP. 1974. "Panorama da conjuntura industrial - aspetos gerais e sectoriais." A Indústria Portuguesa 557 (47): 623-629.

Cordeiro, René. 1976. "Inquérito aos gestores." Pessoal 18 (2): 3-37.

Cordeiro, René, and António Monteiro Fernandes, José Ramirez, David Sequeira. 1980. "Política Governamental e Negociação Coletiva num contexto de crise económica." Pessoal 50/51 (5): 37-60.

Coriat, Benjamin. 1991. "Penser à l'envers»: travail et organisation dans l'enterprise. Paris: Christian Bourgois Editor.

CUF. 1974. O grupo CUF. Lisboa: CUF.

Cunha, Alice. 2012. "O Alargamento Ibérico da Comunidade Económica Europeia: A Experiência Portuguesa." PhD diss., New University of Lisbon. 
Fernandes, António Monteiro. 1983. “«Pacto Social»: o como e o porquê?" Pessoal 2 (8): 7-9.

Fernandes, António Monteiro, René Cordeiro, Luís Maltez, and Orlando Costa. 1980. "Tendências e condicionantes da gestão de recursos humanos em Portugal." Pessoal 59 (5): 91-101.

Fonseca, João. 1979. “Perspetivas da contratação coletiva de trabalho em Portugal." Pessoal 4 (46): 13-27.

Fonseca, Fernando Adão da. 1985. "Flexibilidade e embaratecimento do fator trabalho." Pessoal 13 (10): 12-15.

Foucault, Michel. 1991. "Governmentality." In The Foucault Effect: Studies in Governmental Rationality, edited by G. Burchell, C. Cordon, and P. Miller, 87-104. London: Harvester Wheatsheaf.

Foucault, Michel. 2002. Archaeology of Knowledge. London: Routledge.

Gay, Paul, Graeme Salaman, and Bronwen Rees. 1996. "The Conduct of Management and the Management of Conduct: Contemporary Managerial Discourse and the Constitution of the "Competent" Manager." Journal of Management Studies 33 (3): 263-282.

Gonçalves, Carlos. 1991."A construção social dos quadros nos anos 60: algumas perspetivas de análise." Sociologia 1 (1): 101-164.

Gooderham, Paul, Odd Nordhaug, and Kristen Ringdal. 1999."Institutional and Rational Determinants of Organizational Practices: Human Resource Management in European Firms." Administrative Science Quarterly 44 (3): 507-531.

Guillén, Mauro F. 1994. Models of Management: Work, Authority, and Organization in a Comparative Perspective. Chicago, IL: University of Chicago Press.

ILO. 2016. Portugal: Strikes and Lockouts (1976-1986). Accessed January 3, 2016. http://laborsta.ilo. org/STP/

Indústria Portuguesa. 1959. "Inspirações e objetivos do Instituto Nacional de Investigação Industrial." A Indústria Portuguesa 372 (32): 55-56.

Kavran, Dragoljub. 1976. "A Gestão e seu contexto na Jugoslávia." Pessoal 17 (1): 3-34.

Lains, Pedro. 2003. Os Progressos do Atraso: uma nova história económica de Portugal. Lisboa: Imprensa de Ciências Sociais.

Lains, Pedro, and Lucia Coppollaro. 2013.“Portugal and European Integration, 1947-1992: An Essay on Protected Openness in European Periphery." E-journal of Portuguese History 1 (11): 61-81.

Legge, K. 1995. "HRM: Rhetoric, Reality and Hidden Agendas." In Human Resources Management: A Critical Text, edited by J. Storey, 33-59. London: Routledge.

Lima, Marinús Pires. 1982. «Notas para uma história da organização racional do trabalho em Portugal (1900-80) - alguns resultados preliminares de uma investigação em curso». Análise Social, 72-74 (88): 1299-1366.

Lima, Marinús Pires, and Maria João Rodrigues. 1987. "Trabalho, emprego e transformações sociais: trajetórias e dilemas das ciências sociais em Portugal." Análise Social 95 (23): 119-149.

Logan, John R. 1985. "Democracy from above: Limits to Change in Southern Europe."In Semiperipheral Development: The Politics of Southern Europe in the Twentieth Century, edited by Giovanni Arrighi, 149-177. Beverly Hills: Sage.

Makler, Harry. 1979. "The Portuguese Industrial Elite." In Contemporary Portugal: The Revolution and Its Antecedents, edited by Laurence S. Graham and Harry Makler, 123-165. Austin: University of Texas Press.

Marques, Mercier. 1965. "A Ação da COPRAI." A Indústria Portuguesa 444 (38): 85.

Marques, Jorge. 1984. "Reengenharia e Gestão de Recursos Humanos." Pessoal 66 (9): 11-14.

Marques, Jorge. 1985. "Novos Valores, Poder e Tecnologia na Gestão de Recursos Humanos." Pessoal 14 (10): 28-33.

Noronha, Ricardo. 2013. "'The Most Revolutionary Law Ever Approved': Social Conflict and State Economic Intervention during the Portuguese Revolution (1974-1975)." In The Making of Modern Portugal, edited by Luís Trindade, 290-309. Newcastle-Upon-Tyne: Cambridge Scholars Publishing.

Nunes, Adérito Sedas. 1988. "Histórias, uma história e a História." Análise Social 100 (24): 11-55.

Penim, Paulo Marques. 1984. "Círculos de Qualidade: introdução e conceitos básicos." Pessoal 7 (9): 36-39.

Pinto, Pedro Ramos. 2013. Lisbon Rising: Urban Social Movements in the Portuguese Revolution, 19751974. Manchester, NH: Manchester University Press. 
Rodrigues, Maria de Lurdes. 1999. Os engenheiros em Portugal: profissionalização e protagonismo. Oeiras: Celta.

Rodríguez, Carlos Fernández, and Ernesto R. Gantman. 2011. "Spain and Argentina as Importers of Management Knowledge (1955-2008): A Comparative Analysis." Canadian Journal of Administrative Sciences 28 (2): 160-173.

Rodríguez-Ruiz, Óscar. 2014. "The History of Human Resource Management in Spain: An Autocratic Legacy beyond the Waves of Rational and Normative Control." Management \& Organizational History 9 (3): 256-271. doi:10.1080/17449359.2013.878251

Rosas, Fernando, Francisco Louçã, Jorge Costa, Luís Fazenda, and Cecília Honório. 2010. Os Donos de Portugal: cem anos de poder económico (1910-2010). Porto: Afrontamento.

Santos, Américo Ramos dos. 1977. "Desenvolvimento monopolista em Portugal (fase 1968-73): estruturas fundamentais." Análise Social 49 (13): 69-95.

Seabra, José Augusto. 1985. "O Sistema Educativo e a Modernização da Economia." Pessoal 13 (10): 37-40.

Silva, Manuela. 1958. "O Problema da Comunicação na Empresa". Revista Do Gabinete De Estudos Corporativos 35/36 (9): 283-303.

Silva, M. Tavares. 1982. “Gestão da qualidade e círculos da qualidade - experiência Japonesa." Pessoal 71 (7): 3-10.

Soares, A. Castilho. 1976. “Alocução do presidente da Assembleia Geral da APGTRH." Pessoal 19 (2): 3-5. Xavier, Bernardo. 1976. "Recentes intervenções dos trabalhadores nas empresas." Pessoal 19 (2): 15-24. 